\title{
Correction
}

\section{Correction: Differential Inhibition of the TGF- $\beta$ Signaling Pathway in HCC Cells Using the Small Molecule Inhibitor LY2157299 and the D10 Monoclonal Antibody against TGF- $\beta$ Receptor Type II}

\section{The PLOS ONE Staff}

The authors would like to provide a clarification in relation to Figure $6 \mathrm{~A}$ in the article.

The 30 min HepG2 pSmad2 panel in the published article includes a lane (TGFbeta l+D10) that was slightly edited to remove a background spot. In addition, this panel was generated by juxtaposing lanes that were not adjacent in the original blot, this should have been denoted by vertical black lines and the authors apologize for this omission.

The authors are providing a revised version of Figure 6 that denotes the non-adjacent lanes and where the TGFbetal+D 10 lane reflects that in the original blot. The raw blots for the $30 \mathrm{~min}$ HepG2 pSmad2 panel are also available via this Correction.
Citation: The PLOS ONE Staff (2014) Correction: Differential Inhibition of the TGF$\beta$ Signaling Pathway in HCC Cells Using the Small Molecule Inhibitor LY2157299 and the D10 Monoclonal Antibody against TGF- $\beta$ Receptor Type II. PLOS ONE 9(6): e100604. doi:10.1371/journal.pone.0100604

Published June 12, 2014

Copyright: $\odot 2014$ The PLOS ONE Staff. This is an open-access article distributed under the terms of the Creative Commons Attribution License, which permits unrestricted use, distribution, and reproduction in any medium, provided the original author and source are credited. 
A

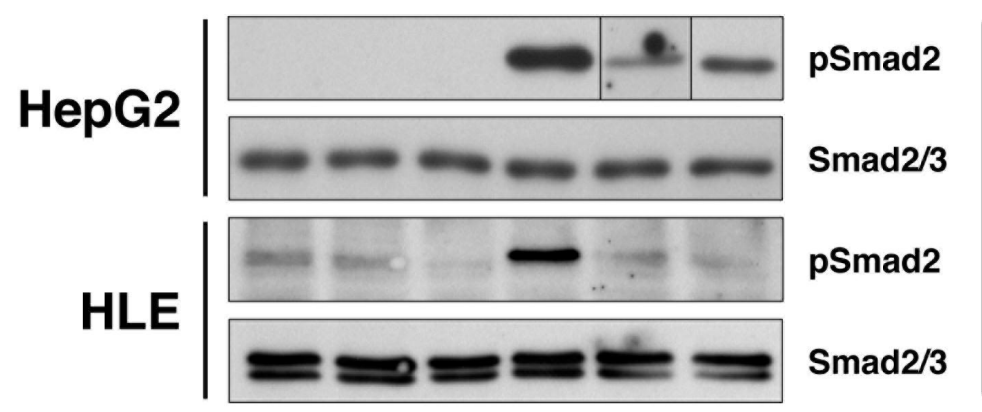

\section{0 min TGF- $\beta 1$}

HepG2

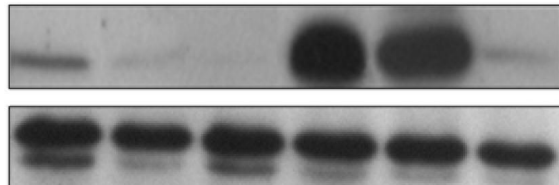

pSmad2

HLE

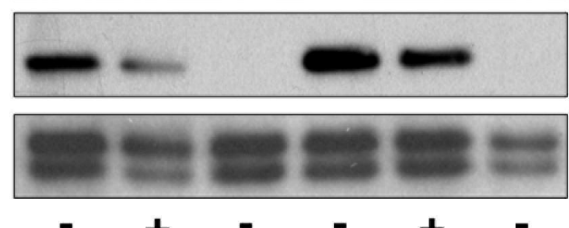

Smad2/3

pSmad2

\section{4 h TGF- $\beta 1$}

Smad2/3

- + - $\quad+\quad+\quad$ - D10 $(25 \mu \mathrm{g} / \mathrm{ml})$

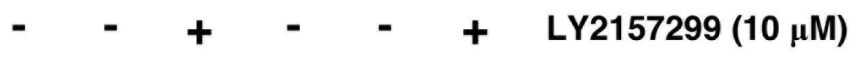

- $\quad-\quad+\quad+\quad+$ TGF- $\beta 1(5 \mathrm{ng} / \mathrm{ml})$

B

\section{Coll-I}

\section{Matrigel}

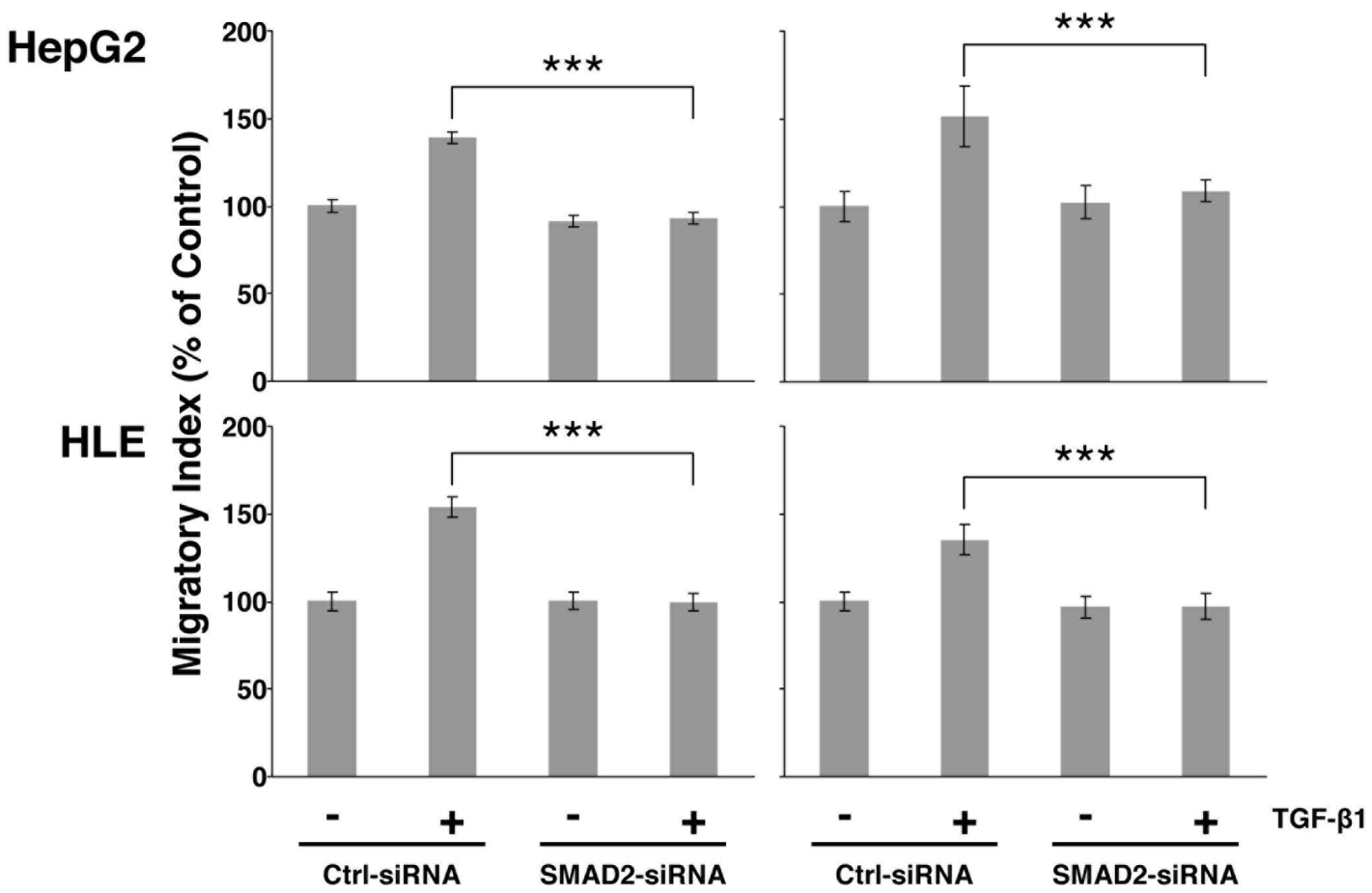

Figure 6. Effect of LY2157299 and D10 on SMAD2 activity in HCC cells. (A) HepG2 and HLE cells were preincubated with LY2157299 (10 $\mu$ M) or D10 $(25 \mathrm{ng} / \mathrm{mL})$ and then stimulated with TGF- $\beta 1(5 \mathrm{ng} / \mathrm{mL})$ in the presence or absence of LY2157299 or D10 for 30 min or 24 hours. Proteins were extracted and western blotting analysis was performed. Phosphorylation of SMAD2 was detected using a rabbit polyclonal antibody directed against phospho-Smad2 (Ser465/467). (B) HepG2 and HLE cells were silenced for SMAD2, or non-silencing control and cell migration assay was performed. Migrated cells were indicated as migratory index versus non TGF- $\beta 1$-stimulated control. ${ }^{* * *} \mathrm{P}<0.001$ versus TGF- $\beta 1$-stimulated control-siRNA. doi:10.1371/journal.pone.0067109.g006 


\section{Supporting Information}

Figure S1. Original raw blot for the $30 \mathrm{~min}$ HepG2, TGFbetal, pSmad2 panel (top panel in Figure 6A).

Figure S2. Original raw blot for the $30 \mathrm{~min}$ HepG2, TGFbetal, Smad2/3 panel (second panel in Figure 6A).

\section{Reference}

1. Dituri F, Mazzocca A, Peidrò FJ, Papappicco P, Fabregat I, et al. (2013) Differential Inhibition of the TGF- $\beta$ Signaling Pathway in HCC Cells Using the Small Molecule Inhibitor LY2157299 and the D10 Monoclonal Antibody against TGF- $\beta$ Receptor Type II. PLoS ONE 8(6): e67109. doi:10.1371/ journal.pone.0067109 